\title{
REMAINING STRAW AND RELEASE OF NUTRIENTS FROM OAT MANAGED IN INTEGRATED CROP-LIVESTOCK
}

\author{
PALHADA REMANESCENTE E LIBERAÇÃO DE NUTRIENTES DA AVEIA PRETA \\ MANEJADA EM SISTEMA DE INTEGRAÇÃO LAVOURA-PECUÁRIA
}

\author{
Eloisa MATTEI ${ }^{1}$; Paulo Sérgio Rabello de OLIVEIRA ${ }^{2}$; Leandro RAMPIM $^{3}$; \\ Jonas Francisco EGEWARTH ${ }^{1}$; Carlos Augusto Rocha de Moraes REGO ${ }^{4}$; \\ Jeferson Tiago PIANO ${ }^{5}$; Juan López de HERRERA ${ }^{6}$
}

1. Doutoranda(0) no Programa de Pós-Graduação em Agronomia, Universidade Estadual do Oeste do Paraná - UNIOESTE, Campus Marechal Cândido Rondon, PR, Brasil. eloisa-mattei@ hotmail.com; 2. Professor, Doutor, UNIOESTE, Campus Marechal Cândido Rondon, PR, Brasil; 3. Professor, Doutor, Universidade Estadual do Centro-Oeste - UNICENTRO, Guarapuava, PR, Brasil; 4.

Mestrando no Programa de Pós-Graduação em Agronomia, UNIOESTE, Campus Marechal Cândido Rondon, PR, Brasil; 5. PósDoutorando no Programa de Pós-Graduação em Agronomia, UNIOESTE, Campus Marechal Cândido Rondon, PR, Brasil; 6. Professor, Doutor, Universidad Politécnica de Madrid - UPM, Madrid - Espanha.

\begin{abstract}
This study aimed to evaluate the decomposition and nutrient release from residues of the culture of oats and fallow in crop-livestock integration system. The experimental design was a randomized complete block design with two replications, as parcels being formed by four managements (fallow, oats without grazing, oats grazed once and twice), and the subplots for evaluation periods along the soybean crop in succession (0, 10, 20, 30, 50, 100 and 120 days after sowing). The residual amounts of dry matter and the contents of Carbon $(\mathrm{C})$, Nitrogen $(\mathrm{N})$, Phosphorus (P) and Potassium (K) were determined. Oats without grazing and fallow with natural reappearance of turnip + ryegrass were the treatments that presented the highest amount of dry matter remaining, reaching 5,219 and 6,781 kg ha ${ }^{-1}$, respectively. The amount of nutrients, N, P and K released from the residues, were similar independent from the management adopted, with exponential reduction proportional to the reduction of the remaining dry matter. $\mathrm{K}$ was the nutrient released faster from the residues and should be considered at the time of fertilization calculation of the culture to be implanted. The integrated crop-livestock system in which takes place one and two grazing oats, even reducing soil cover, enables high nutrient cycling.
\end{abstract}

KEYWORDS: Avena Strigosa. Cultural waste. Half-life time.

\section{INTRODUCTION}

The use of black oats (Avena Strigosa Schreb.) in southern Brazil as a cover crop or as feed for the animals during the winter period has been shown to be an efficient strategy for the notillage system (SPD), erosion control and in the nutrient cycling, preceding the cultivation of soybean and corn in the summer.

The conservation management depends on the use of various agricultural practices, highlighting the crop and livestock integration systems (CLI), due to which are activities that complement each other. However, the guarantee of success of this system will depend on the proper management of the components involved, soil, plant and animal, which interact with each other (VILELA et al., 2011).

As an alternative to increase the productivity of crops of economic interest and reduce costs with fertilizers, management strategies have been used to increase the efficiency of fertilization, reduce environmental impacts and improve income for the producer. Among these alternatives, we highlight the use of cover crops before commercial crops, which are able to extract the nutrients from the deepest layers of the soil, through the root system (MELO et al., 2011), to provide a satisfactory amount of phytomass on the soil surface, and with the decomposition, to release nutrients to successor crops, reducing production costs (TEIXEIRA et al., 2011).

However, there are several factors that can influence the persistence of plant residues on the surface of the soil, such as the chemical composition of the plant material and the soil and climatic conditions of each region (SOUZA et al., 2010). So, the faster the decomposition, the faster the nutrients will be released.

For Crusciol et al. (2008), black oats are among the cover crops that decompose and release nutrients to the soil in a slow and gradual way, when compared to the fodder turnip, in which the decomposition and release of nutrients is fast and intense. In addition, the same authors estimate that black oats are responsible for about $30 \%$ of the cultivation in relation to the other species used as cover plant. Aita and Giacomini (2003) observed 
that about $81 \%$ of the dried phytomass produced by oats still remained on the soil surface 30 days after the management when grown single.

The accumulation of nutrients by the plants in the crop-livestock integration system as well as their availability, are factors that may be associated with the handling of the components involved. In this way, nutrient release studies of the cover crops become indispensable, to better understand the croplivestock integration system.

In view of the above, the objective of this work was to evaluate the decomposition and nutrient release of the black oat and fallow crop residues, conducted in a crop-livestock integration system with the soybean crop in succession.
MATTEI, E. et al.

The work was conducted in field conditions, in the 2016/2017 harvest, at the Experimental Farm "Professor Antônio Carlos dos Santos Pessoa", belonging to the State University of the West of Paraná - UNIOESTE, Câmpus Marechal Cândido Rondon, located in the western region of Paraná, latitude $24^{\circ} 31^{\prime} 58$ "S and longitude $54^{\circ} 01^{\prime} 10^{\prime \prime} \mathrm{W}$, with an altitude of approximately $400 \mathrm{~m}$.

The soil is classified as a very clayey Eutrophic Red Latosol (SANTOS et al., 2013) and the climate of the region, according to Köppen classification is Cfa type, humid subtropical climate, with average temperatures varying between $17^{\circ} \mathrm{C}$ and $19^{\circ} \mathrm{C}$ and mean annual rainfall of $1,500 \mathrm{~mm}$ (CAVIGLIONE et al., 2000). The climatic data for the experimental period (Figure 1) were obtained from the Automatic Climatological Station of the Nucleus of Experimental Stations of UNIOESTE, located near the experimental area.

\section{MATERIAL AND METHODS}

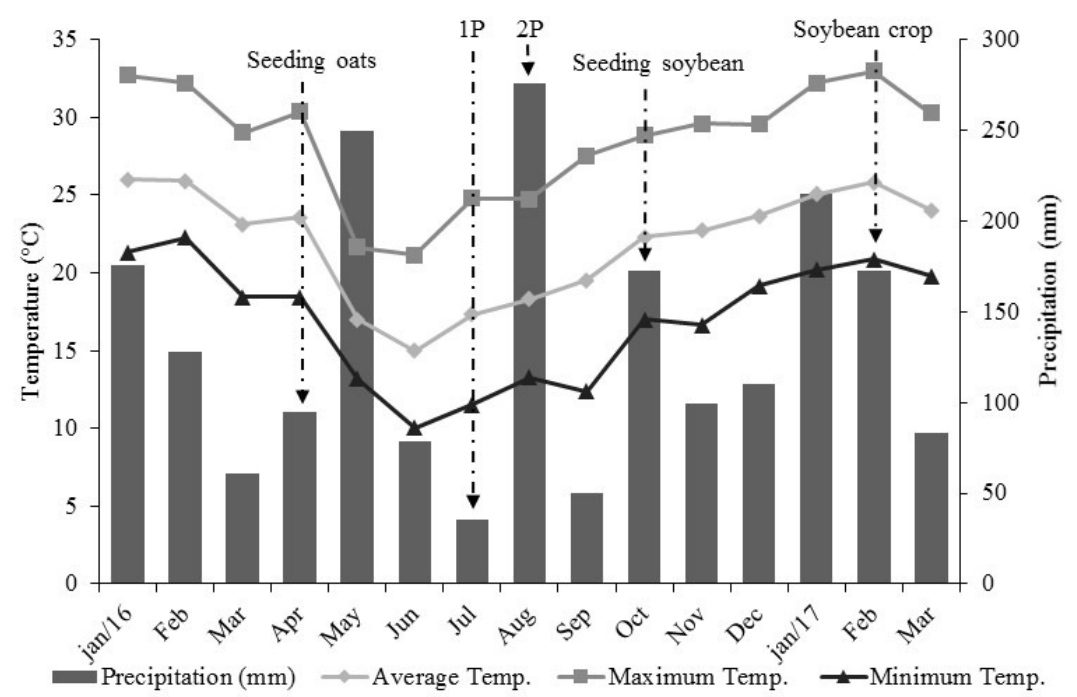

Figure 1. Monthly averages of maximum, average and minimum air temperatures and monthly cumulative rainfall during the period of conduction of the experiment. $1 \mathrm{P}$ and $2 \mathrm{P}$ : first and second grazing, respectively, of black oats in the winter of 2016.

Source: UNIOESTE, Marechal Cândido Rondon - PR.

The area was being managed in a croplivestock integration system and with the same management for four years, in direct sowing. One year before the experiment implementation (2015), there was liming in the area. In March 2016, soil sampling was performed for the chemical characterization, of the $0-20 \mathrm{~cm}$ layer, which presented the following results: $\mathrm{pH}$ em $\mathrm{CaCl}_{2}: 4,42$; MO: $31,44 \mathrm{~g} \mathrm{dm}^{-3}$; P: $26,93 \mathrm{mg} \mathrm{dm}{ }^{-3} ; \mathrm{Ca}^{+2}: 4,24$ $\mathrm{cmol}_{\mathrm{c}} \mathrm{dm}^{-3}, \mathrm{Mg}^{+2}: 2,79 \mathrm{cmol}_{\mathrm{c}} \mathrm{dm}^{-2}, \mathrm{~K}^{+}: 0,56 \mathrm{cmol}_{\mathrm{c}}$ $\mathrm{dm}^{-3}, \mathrm{Al}^{+3}: 0,27 \mathrm{cmol}_{\mathrm{c}} \mathrm{dm}^{-3}, \mathrm{H}^{+}+\mathrm{Al}^{3+}: 6,37 \mathrm{cmol}_{\mathrm{c}}$ $\mathrm{dm}^{-3}$ e V\%: 54,44 .

The experimental design was a randomized block in a split plot design with two replications. In the plots $\left(50 \mathrm{~m}^{2}\right)$ were allocated the four management: without grazing, a grazing with a height of $15 \mathrm{~cm}$ and two grazing with a height of 15 $\mathrm{cm}$ and fallow. In the plots destined to the fallow treatment, only the spontaneous vegetation was developed (natural resting area of predominant species, ryegrass (Lolium multiflorum) and turnip (Brassica napus L.). The subplots were composed of periods of collection of litter bags during the cultivation of soybean $(0,10,20,30,50,100$ and 120 days after sowing (DAS)).

The oat crop was sown in the fall/winter period, on April 13, 2016, in a mechanized and direct way on the soybean straw, using $60 \mathrm{~kg} \mathrm{ha}^{-1}$ of 
black oat seeds, cultivar IAPAR 61 at $0,17 \mathrm{~m}$ line spacing. Basal fertilization was performed using 250 $\mathrm{kg} \mathrm{ha}^{-1}$ of the formulated 10-15-15 $\left(\mathrm{N}, \mathrm{P}_{2} \mathrm{O}_{5}\right.$ and $\mathrm{K}_{2} \mathrm{O}$ ) and for cover fertilization, $120 \mathrm{~kg} \mathrm{ha}^{-1}$ of $\mathrm{N}$ as urea.

The oat cover fertilization was performed manually, in the treatment grazed twice, the fertilization was divided of three times, being an application at the beginning of the tillering and soon after each grazing. For treatments that underwent only one grazing and/or that were not grazed, the cover fertilization was split of two times, one tillering and the other after the first grazing. Regarding phytosanitary treatments during the oat cycle, there was no need to apply herbicides, insecticides and/or fungicides.

When the plants were between 25 and 35 $\mathrm{cm}$ in height, the management of the plots was started (except at the fallow and without grazing), using twelve animals of the dutch breed in the lactation phase, with an average weight of $650 \mathrm{~kg}$. The grazing was carried out for four hours a day, two in the morning and two in the afternoon, or until the remained reached about $15 \mathrm{~cm}$, so that no damage to the apical meristem of the plants occurred. With the removal of the animals, the area remained closed for a period of 30 days, after this period the second grazing was done in the same way as the first one. Grazing was started at 86 and 116 days after sowing (DAS).

For the implantation of the summer crop, the area was previously desiccated, 36 days after the second grazing. The sowing of soybean was carried out in a no-tillage system in the straw, on October 21, 2016, about 20 days after desiccation, using NIDERA 5909 RR cultivar, $0.50 \mathrm{~m}$ spacing between lines, $4 \mathrm{~cm}$ deep and 14 seeds per linear meter. For the basic fertilization $310 \mathrm{~kg} \mathrm{ha}^{-1}$ of the commercial formulation 02-20-18 $\left(\mathrm{N}, \mathrm{P}_{2} \mathrm{O}_{5}\right.$ and $\left.\mathrm{K}_{2} \mathrm{O}\right)$ was used.

One day before seeding of soybean, of was determined dry matter yield of oats, estimated by sampling with a known area of metallic square $(0.25$ $\mathrm{m}^{2}$ ). The evaluation of decomposition and nutrient release of the straw was carried out by the litter bag method (KLIEMANN et al., 2006) with a dimension of $0.20 \times 0.30 \mathrm{~m}$, being placed on the surface the soil. To fill the litter bags, the material passed by drying in forced circulation oven at $65^{\circ} \mathrm{C}$, subsequently acondicionou $30 \mathrm{~g}$ of this material in each pocket without being cut into fragments.

At each treatment, 12 litter bags were distributed on the soil surface. Six samples were collected, two bags per collection, at 0 days after sowing (DAS), 10, 20, 30, 50, 100 and 120 DAS. After the pockets were collected, the plant material was sifted to remove the adhered soil and taken to the stove $\left(65^{\circ} \mathrm{C}\right.$ up to constant weight) for later weighing and grinding in a Willey mill. They were determined contents of $\mathrm{C}, \mathrm{N}, \mathrm{P}$ and $\mathrm{K}$. C was obtained from the determination of organic matter in muffle as described by Silva and Queiroz (2006).

For determination of N, P and $\mathrm{K}$, the plant material was subjected to sulfuric acid digestion. In the extracts, the amount of $\mathrm{N}$ was determined by the distillation in Kjeldahl semi-micro system, as described by Tedesco et al. (1995), P was determined by UV-VIS spectrophotometry according to Braga and Defelipo (1974), while K was determined by flame photometry (MALAVOLTA et al., 1997).

From the results obtained, the straw decomposition and nutrient release rates of the remaining dry matter were determined using the exponential mathematical model, $X=X o \cdot e^{-k t}$ (THOMAS and ASAKAWA, 1993), where $X$ is the amount of dry matter or nutrients remaining; $t$ is a period of time in days; Xo refers to the amount of dry matter at the beginning of decomposition and; $k$ is the decomposition constant. With the value of $\mathrm{k}$, the half-life $\left(\mathrm{t}^{1} / 2=0.693 / \mathrm{k}\right)$ was calculate, which expresses the time required for half of the straw to decompose or half of the nutrients contained in the residues to be released (Paul and Clark, 1989).

The obtained data were submitted to analysis of variance with application of Test $\mathrm{F}$ between the treatments using the SISVAR software (Ferreira, 2011). When they had significance, the regression equation was adjusted using SigmaPlot ${ }^{\circledR}$ 13.0 software. The choice of the type of model that best fit each data set was made based on the significance of the parameters of the equation and the coefficient of determination $\left(\mathrm{R}^{2}\right)$, which indicates the degree of association between the observed values and the adjusted model.

\section{RESULTS AND DISCUSSION}

The interaction between the managements factors (without grazing, one grazing, two grazing and fallow) and decomposition time (0, 10, 20, 30, 50, 100 and 120 DAS) was significant for all the studied variables: dry matter, carbon, nitrogen, phosphorus and potassium $\left(\mathrm{kg} \mathrm{ha}^{-1}\right)$.

Regarding adopted managements, it was observed exponential decrease of the remaining dry matter. This loss was more pronounced in oats grazed once and twice, where there was reduction of $68 \%$ and $66 \%$ at 120 DAS, respectively (Figure 2). This may have occurred as a result of the material have budding, providing increased number of leaves 
and stems increased number of tillers, compared to treatment with less intensity grazing. Assmann et al. (2014), working with dual-purpose wheat and different grazing intensities, observed that the residual material decomposed more rapidly with an increase in grazing intensity.

Contradictory results were observed by Medrado et al. (2011), evaluating the residual dry matter decomposition of different winter coverages, in which the presence of the animal reduced the rate of decomposition of the cultural residues in relation to the fallow.

The authors attributed this fact, due to the greater amount of dry matter produced where grazing did not occur, which possibly influenced the temperature and humidity of the soil, favoring the survival and growth of the population of organisms decomposers, increasing the rate of decomposition this residue.

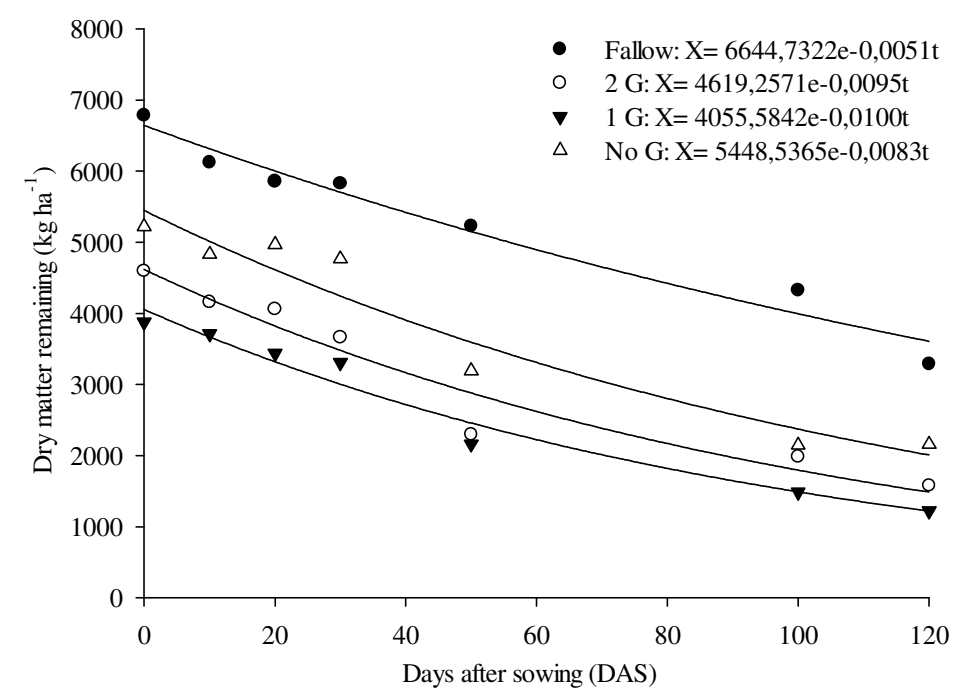

Figure 2. Residual dry matter of management residues, fallow, 2 grazing (2 G), 1 grazing (1 G) and no grazing (No G), conducted in a crop-livestock integration.

After 120 days of soybean seeding, there was remaining $51 \%, 41 \%, 34 \%$ and $32 \%$ of the initial amount of dry matter on the soil fallow, oats without grazing, oats with two grazing and oats grazed one respectively. This can be explained by the higher amount of lignin and lower content of soluble sugars and nitrogen in the older plant residues (fallow and oats without grazing) compared to younger residues (one and two times grazed oats), making the decomposition more Slow (SANAULLAH et al., 2010).

The longest half-life $\left(\mathrm{T}^{1 / 2}\right)$ of the remaining biomass was checked for fallow, with 136 days (Table 1) and the lowest for the managements with one and two grazing (69 and 73 days, respectively), this is because the spontaneous vegetation which developed in this area consist predominantly of two species: ryegrass (Lolium multiflorum) and turnip (Brassica napus L.) species that present a great capacity for natural seeding and remain in the area from one year to another.

Possibly due to the high $\mathrm{C} / \mathrm{N}$ ratio of the residues produced in the fallow (35) of relation to grazing managed once and twice (21 and 16.4, respectively), not only because it possesses a species of Poaceae family, but ffor not received any type of nitrogen fertilization, either sowing, or covering. According to Lobo et al. (2012), as the $\mathrm{N}$ concentration increases in plant tissue, the $\mathrm{C} / \mathrm{N}$ ratio tends to be reduced.

The rate of decomposition of the cultural residues as well as the amount of nutrients provided by the oats for the subsequent crop is important because they allow to verify if this straw will be enough to meet the nutrient demand, total or partial, or if there is a synchronism between the time of greater release of nutrients and demand for the successor culture (CALONEGO et al., 2012).

In addition, it is worth mentioning that the presence of cultural residues on the surface preserves the soil against the impact of the rain drop, reducing the risk of erosion, maintaining humidity, increasing the input of organic matter and, consequently, favoring the physical quality and soil chemistry. 
Table 1. Parameters of the fitted models $(X=X o . e-k t)$ to the values of dry matter, nitrogen, phosphorus and carbon remaining, half-life $\left(\mathrm{T}^{1 / 2}\right)$ and $\mathrm{R}^{2}$ values of the managements in crop-livestock integration system

\begin{tabular}{|c|c|c|c|}
\hline Managements & $\mathrm{k}^{(1)}$ & $T^{1 / 2(2)}$ Days & $\mathrm{R}^{2}$ \\
\hline \multicolumn{4}{|c|}{ Remaining dry matter } \\
\hline Fallow & 0,0051 & 136 & $0,96^{* *}$ \\
\hline 2 Grazing & 0,0095 & 73 & $0,95 * *$ \\
\hline 1 Grazing & 0,0100 & 69 & $0,97 * *$ \\
\hline Without Grazing & 0,0083 & 83 & $0,94 * *$ \\
\hline \multicolumn{4}{|c|}{ Remaining total carbon } \\
\hline Fallow & 0,0053 & 131 & $0,93^{* *}$ \\
\hline 2 Grazing & 0,0100 & 69 & $0,97 * *$ \\
\hline 1 Grazing & 0,0103 & 67 & $0,98 * *$ \\
\hline Without Grazing & 0,0085 & 82 & $0,97 * *$ \\
\hline \multicolumn{4}{|c|}{ Remaining nitrogen } \\
\hline Fallow & 0,0039 & 178 & $0,63^{* * *}$ \\
\hline 2 Grazing & 0,0137 & 51 & $0,92 * *$ \\
\hline 1 Grazing & 0,0096 & 72 & $0,84 * *$ \\
\hline Without Grazing & 0,0056 & 124 & $0,75 * *$ \\
\hline \multicolumn{4}{|c|}{ Remaining phosphorus } \\
\hline Fallow & 0,0030 & 231 & $0,68 * *$ \\
\hline 2 Grazing & 0,0155 & 45 & $0,81 * *$ \\
\hline 1 Grazing & 0,0219 & 32 & $0,94 * *$ \\
\hline Without Grazing & 0,0060 & 116 & $0,74 * *$ \\
\hline \multicolumn{4}{|c|}{ Remaining potassium } \\
\hline Fallow & 0,0782 & 9 & $0,97 * *$ \\
\hline 2 Grazing & 0,0748 & 9 & $0,93 * *$ \\
\hline 1 Grazing & 0,0512 & 14 & $0,96 * *$ \\
\hline Without Grazing & 0,0323 & 21 & $0,79 * *$ \\
\hline
\end{tabular}

${ }^{(1)}$ Decomposition constant; ${ }^{(2)}$ Half-life time; ** Significant at $1 \%$ by the $\mathrm{F}$ test.

The total carbon (C) presented similar behavior to the remaining dry matter, that is, the loss of $\mathrm{C}$ of the residue was proportional to the loss of mass of the remaining dry matter (Figure $3 \mathrm{~A}$ ).

The largest amount of accumulated $\mathrm{C}$ in the remaining dry matter and half-life $\left(\mathrm{T}^{1 / 2}\right)$ were observed for fallow about $3600 \mathrm{~kg} \mathrm{ha}^{-1}$ (Figure 3A) and 131 days (Table 1). At the end of the 120 DAS about $55 \%$ of the $\mathrm{C}$ had been released. Already, the greatest losses were observed with the cultural residues of oats with a grazing, about $70 \%$ at 120 DAS.

The total $\mathrm{C}$ is used by microorganisms, especially fungi and bacteria, which colonize plant residues as an energy source, which is released as carbon dioxide $\left(\mathrm{CO}_{2}\right)$ into the atmosphere (MANZONI et al., 2008). This way, due to the high average temperature and precipitation occurred during the experimental period (Figure 1), these factors may have contributed to the colonization of the residues by these microorganisms.

Being the most extracted nutrient, nitrogen (N) presented the highest accumulation in dry matter. We highlight the management of oats with two grazing, where the initial amount (0 DAS) of $\mathrm{N}$ in the plant tissue is approximately $164 \mathrm{~kg} \mathrm{ha}^{-1}$. Possibly due to the structural differentiation that grazing caused, promoting greater density of tillers and consequently of leaves, associated to the high mobility of the nutrient being directed to regions where there is a higher growth rate due to regrowth. However, their release occurred rapidly, up to 120 DAS around $71 \%$ of the $\mathrm{N}$ accumulated in the residual dry matter had been released (Figure 3B), presenting the shortest half-life, 51 days (Table 1).

Amado et al. (2003), evaluating oat and vetch decomposition, observed that the vetch released a greater amount of $\mathrm{N}$ (about $55 \mathrm{~kg} \mathrm{ha}^{-1}$ at 90 days after management), whereas in the oat + vetch consortium there was a reduction in the release of this nutrient. Likewise, Aita and Giacomini (2003) observed that the vetch had 60\% of the initial $\mathrm{N}$ in the cultural residues in the first 15 days of evaluation, whereas in the turnip and oats, this value was higher than $90 \%$. 

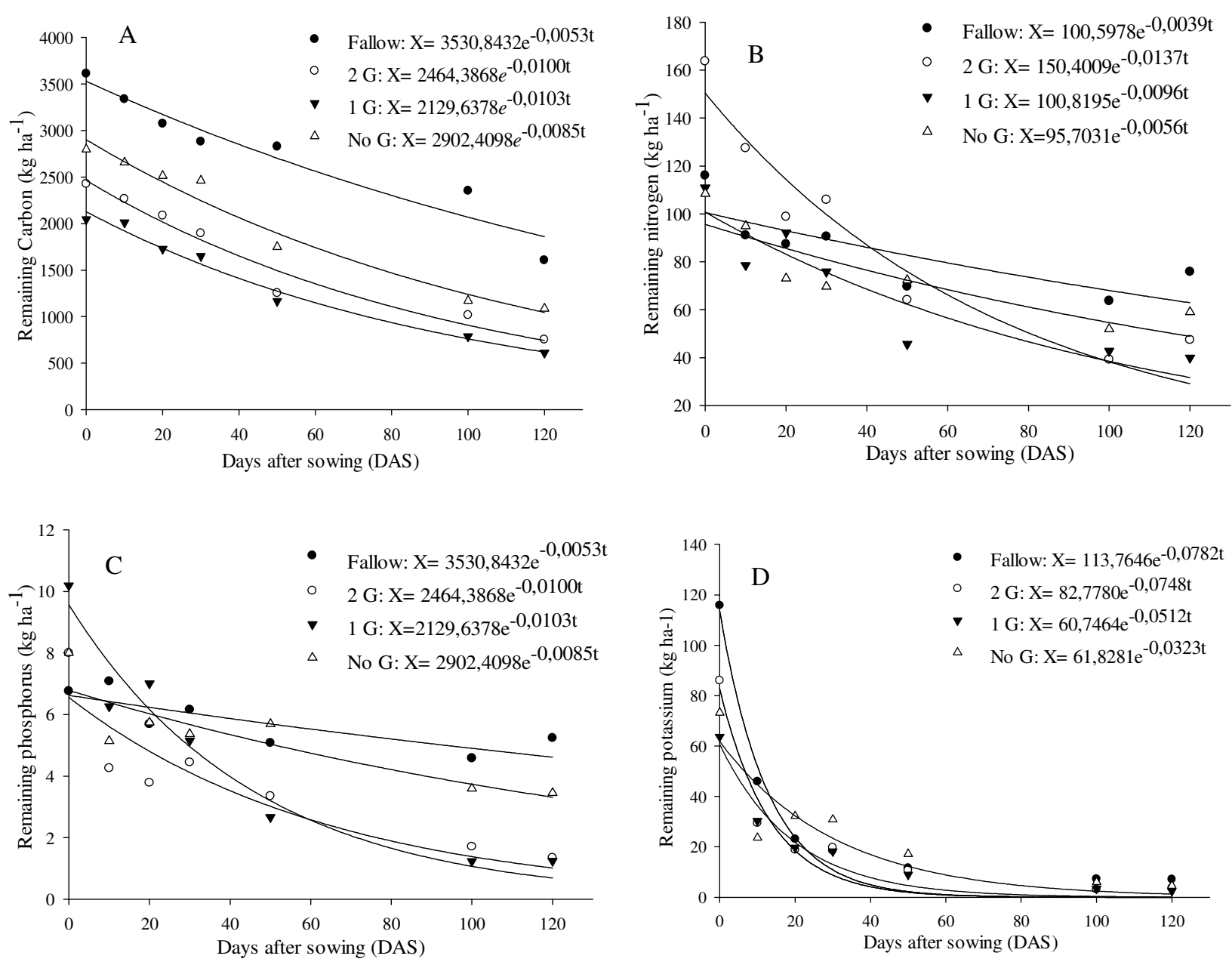

Figure 3. Figure 3. Carbon (a), nitrogen (B), phosphorus (c) and remaining potassium (d) (kg ha-1) of the waste management systems, fallow, grazing 2 (G 2), grazing $1(1 \mathrm{G})$ and no grazing (No $G)$ in evaluations carried out over time (The equation and the significance of the adjustments are presented in Table 1).

In relation to the phosphorus $(\mathrm{P})$, it was observed that the initial amount in the residues of the managements adopted for oats $(1 \mathrm{G}, 2 \mathrm{G}$ and without $G$ ) were higher than in fallow, a fact that can be explained due to the fertilization of base at the time of oat implantation (Figure 3C). However, the half life time $\left(\mathrm{T}^{1 / 2}\right)$ of these handlings were lower, 32, 45 and 116 days for the aforementioned management systems, respectively, when compared to fallow of 231 days (Table 1).

The longer half-life $\left(\mathrm{T}^{1 / 2}\right)$ of $\mathrm{P}$ for fallow, can be attributed to the higher dry matter production (Figure 2) and high $\mathrm{C} / \mathrm{N}$ ratio. In addition, because it is a nutrient found in organic form in plant residues, its release is considered slow, reducing the possibility of retention to the oxides-hydroxides of iron and aluminum (SILVA NETO et al., 2008), making its use more efficient compared to use of readily soluble mineral fertilizers.

The longer half-life $\left(\mathrm{T}^{1} / 2\right)$ of $\mathrm{P}$ for fallow, can be attributed to the higher dry matter production (Figure 2) and high $\mathrm{C} / \mathrm{N}$ ratio. In addition, because it is a nutrient found in organic form in plant residues, its release is considered slow, reducing the possibility of retention to the oxides-hydroxides of iron and aluminum (SILVA NETO et al., 2008), making its use more efficient compared to use of readily soluble mineral fertilizers.

Potassium (K) was the second nutrient most extracted by plants, presenting having greater time of half-life $\left(\mathrm{T}^{1 / 2}\right)$ of 14 and 21 days, for residues from grazed oats once and without grazing, in relation to the other treatments (9 days) (Table 1). Likewise, Santos et al. (2014), evaluating the release of K from corn straw + Brachiaria ruziziensis after 
desiccation of the area, observed a half-life $\left(\mathrm{T}^{1 / 2}\right)$ of 13 days. These results were lower than those obtained by Torres and Pereira (2008), studying the dynamics of $\mathrm{K}$ in the vegetal residues of cover crops in the Cerrado, where the climate is classified as Aw, tropical hot, with annual average temperature ranging from $29^{\circ} \mathrm{C}$ to $16.9^{\circ} \mathrm{C}$ and mean precipitation of $64.9 \mathrm{~mm}$, in which the time of half-life of oats ranged from 110 to 130 days in two years of evaluations.

In the first days of evaluation, the velocity release rate of $K$ of the remaining dry matter was rapid; at $50 \mathrm{DAS}$, the average residual $\mathrm{K}$ value of the managements adopted was around $12 \mathrm{~kg} \mathrm{ha}^{-1}$. At 100 DAS, all residues, regardless of the management adopted, practically reached the total release of this nutrient, that is, it can be considered a use of almost $100 \%$ of the $\mathrm{K}$ of the straw for the crop in succession.

According to Mendonça et al. (2015), the rate at which nutrient release occurs during the process of decomposition of cultural residues will depend on the shape and location of these in the plant tissue. The $\mathrm{K}$, because it is not a component and does not have structural function in the cells of the plants, it's easy to release (GIACOMINI et al., 2003). After desiccation, the concentration of this nutrient in the tissue is reduced, o it is easily washed by rainwater after the rupture of the plasma membranes (CRUSCIOL et al., 2008).

Whereas the period of greatest nutritional requirement soybean begins around 30 days after emergence and keeps high until the early grain filling (CARMELLO; OLIVEIRA, 2006), possibly the use of $\mathrm{K}$ released by crop residues was elevated.

\section{CONCLUSIONS}

Oats without grazing and fallow with natural seeding of forage turnip + ryegrass were the treatments that presented the highest yields of remaining dry matter, reaching 5,219 and 6,781 kg $\mathrm{ha}^{-1}$, respectively.

The amount of nutrients released, N, P and $\mathrm{K}$ of the residues, regardless of the management adopted, was similar, with exponential and progressive decrease of the dry matter.

Potassium was the nutrient released faster from cultural residues, and should be considered at the time of crop fertilizer recommendation to be implemented in succession.

The integration of crop-livestock system where it is held one and two grazing of oats, even reducing the soil cover enables high nutrient cycling for the successor crop.

\section{ACKNOWLEDGMENTS}

The authors would like to thank the National Council for Scientific and Technological Development $(\mathrm{CNPq})$ the productivity grant in research (process 304344/2014-1) awarded to the researcher Dr. Paulo Sérgio Rabello de Oliveira and the Coordination for the Improvement of Higher Education Personnel (Capes) for the granting of the scholarship.

RESUMO: O objetivo do trabalho foi avaliar a decomposição e liberação de nutrientes dos resíduos da cultura da aveia preta e do pousio conduzidos em sistema de integração lavoura-pecuária. O delineamento experimental utilizado foi o de blocos casualizados, em esquema de parcelas subdivididas, com duas repetições, sendo as parcelas constituídas por quatro manejos (pousio, aveia sem pastejo, aveia pastejada uma e duas vezes) e as subparcelas, pelas épocas de avaliação ao longo do cultivo da soja em sucessão $(0,10,20,30,50,100$ e 120 dias após a semeadura). Foram determinadas as quantidades residuais de matéria seca e os teores de Carbono (C), Nitrogênio (N), Fósforo (P) e Potássio (K). A aveia sem pastejo e o pousio com ressemeadura natural de aveia + azevém, foram os manejos que apresentaram as maiores quantidades de matéria seca remanescentes, chegando a 5.219 e $6.781 \mathrm{~kg} \mathrm{ha}^{-1}$, respectivamente. A quantidade dos nutrientes, N, P e K liberados dos resíduos, foram semelhantes independente do manejo adotado, com redução exponencial e proporcional à redução da matéria seca remanescente. $\mathrm{O} \mathrm{K}$ foi o nutriente liberado mais rapidamente dos resíduos e deve ser considerado no momento do cálculo de adubação da cultura a ser implantada. O sistema de integração lavoura-pecuária no qual se realiza um e dois pastejos da aveia, mesmo reduzindo a cobertura do solo, possibilita elevada ciclagem de nutrientes.

PALAVRAS-CHAVE: Avena Strigosa. Resíduos culturais. Tempo de meia vida.

\section{REFERENCES}


AITA, C.; GIACOMINI, S. J. Decomposição e liberação de nitrogênio de resíduos culturais de plantas de cobertura de solo solteiras e consorciadas. Revista Brasileira Ciência do Solo, Viçosa, v. 27, n. 4, p. 601-612, jul./ago. 2003.

AMADO, T. J. C.; SANTI, A.; ACOSTA, J. A. A. Adubação nitrogenada na aveia preta. II influencia na decomposição de resíduos, liberação de nitrogênio e rendimento de milho sob sistema plantio direto. Revista Brasileira Ciência do Solo, Viçosa, v. 27, n. 6, p. 1085-1096, dez. 2003.

ASSMANN, T. S.; BORTOLLI, M. A. de; ASSMANN, A. L; SOARES, A. B.; PITTA, C. S. R.; FRANZLUEBBERS, A. J.; GLIENKE, C. L.; ASSMANN, J. M. Does cattle grazing of dual-purpose wheat accelerate the rate os stubble decomposition and nutrientes released? Agriculture, Ecosystems \& Environment, Amsterdam, v. 190, n. 1, p. 37-42, jun. 2014. https://doi.org/10.1016/j.agee.2014.01.011

BRAGA, J. M; DEFELIPO, B. V. Determinação espectrofotométrica de fósforo em extratos de solo e material vegetal. Revista Ceres, Viçosa, v. 21, n. 113, p. 73-85, set. 1974.

CALONEGO, J. C.; GIL, F. C.; ROCCO, V. F.; SANTOS, E. A. Persistência e liberação de nutrientes da palhada de milho, braquiária e labe-labe. Bioscience Journal, Uberlândia, v. 28, n. 5, p. 770-781, set./out. 2012.

CARMELLO, Q. A. C.; OLIVEIRA, F. A. Nutrição de lavouras de soja: situação atual e perspectivas. Visão Agrícola, Piracicaba, v. 3, n. 5, p. 8-11, jan./jun. 2006.

CAVIGLIONE, J. H.; KILHL, L. R. B.; CARAMORI, P. H.; OLIVEIRA, D. Cartas climáticas do Paraná. Londrina: IAPAR. 2000. CD-ROM.

CRUSCIOL, C. A. C.; MORO, E.; LIMA, E, V.; ANDREOTTI, M. Taxas de decomposição e liberação de macronutrientes da palhada de aveia preta em plantio direto. Bragantia, Campinas, v. 67, n. 2, p. 481-489, 2008. https://doi.org/10.1590/S0006-87052008000200024

FERREIRA, D. F. Sisvar: a computer statistical analysis system. Ciência e Agrotecnologia, Lavras, v. 35, n. 6, p. 1039-1042, nov./dec. 2011.

GIACOMINI S. J.; AITA, C.; HUBNER, A. P.; LUNKES, A.; GUIDINI, E.; AMARAL, E. B. Liberação de fósforo e potássio durante a decomposição dos resíduos culturais em plantio direto. Pesquisa Agropecuária Brasileira, Brasília, v. 38, n. 9, p.1097-1104, set. 2003. https://doi.org/10.1590/S0100-204X2003000900011

KLIEMANN, H. J.; BRAZ, A. J. B. P.; SILVEIRA, P. M. Taxa de composição de resíduos de espécies de cobertura em Latossolo Vermelho distroférrico. Pesquisa Agropecuária Tropical, v. 36, n. 1, p. 21-28, abr. 2006.

LOBO, T. F.; GRASSI FILHO, H.; BULL, L. T. Rendimento de massa de matéria seca e relação C/N da aveia preta em função do lodo de esgoto e adubação nitrogenada. Biosciense Journal, Uberlândia, v. 28, n. 2, p. 224234, mar./abr. 2012.

MALAVOLTA, E.; VITTI, G. C.; OLIVEIRA, S. A. Avaliação do estado nutricional das plantas: princípios e aplicações. 2. ed. Piracicaba: POTAFOS, 1997. 319 p.

MANZONI, S.; JACKSON, R. B.; TROFYMOW, J. A.; PORPORATO, A. The global stoichiometry of litter nitrogen mineralization. Science, v. 321, n. 1, p. 684-686, aug. 2008. https://doi.org/10.1126/science.1159792

MEDRADO, R. D.; RIOS, E. M; LOPES, E. C. P; CARVALHO, P. C. F.; MORAES, A.; LANG, C. R. Decomposição de resíduos culturais e liberação de nitrogênio para a cultura do milho. Scientia Agraria, Curitiba, v. 12, n. 2, p. 097-107, mar./abr. 2011. 
MELO, A.V.; GALVÃO, J. C. C.; BRAUN, H. SANTOS, M. M.; COIMBRA, R. R.; SILVA, R. R.; REIS, W. F. Extração de nutrientes e produção de biomassa de aveia preta cultivada em solo submetido a dezoito anos de adubação orgânica e mineral. Semina: Ciências Agrárias, Londrina, v. 32, n. 2, p. 411-420, abr./jun. 2011. https://doi.org/10.5433/1679-0359.2011v32n2p411

MENDONÇA, V. Z.; MELLO, L. M. M.; ANDREOTTI, M.; PARIZ, C. M.; YANO, E. H.; PEREIRA, F. C. B. L. Liberação de nutrientes da palhada de forrageiras consorciadas com milho e sucessão com soja. Revista Brasileira de Ciência do Solo, Viçosa, v. 39, n. 1, p. 183-193, jan. 2015.

PAUL, E. A.; CLARK, F. E. Soil microbiology and biochemistry. Oxford, 1. ed. San Diego, Academic Press. $1989,275 \mathrm{p}$.

SANTOS, H. G.; ALMEIDA, J. A.; OLIVEIRA, J. B.; LUMBRERAS, J. F.; ANJOS, L. H. C. dos; COELHO, M. R.; JACOMINE, P. K. T.; CUNHA, T. J. F.; OLIVEIRA, V. A. de. Sistema Brasileiro de Classificação de Solos. 3.ed. Brasília, DF, EMBRAPA, 2013. 353p.

SANTOS, F. C.; ALBUQUERQUE FILHO, M. R.; VILELA, L.; FERREIRA, G. B.; CARVALHO, M. C. S.; VIANA, J. H. M. Decomposição e liberação de macronutrients da palhada de milho e braquiária, sob integração lavoura-pecuária no Cerrado Baiano. Revista Brasileira de Ciência do Solo, Viçosa, v. 38, n. 6, p. 1855-1861, nov./dez. 2014.

SANAULLAH, M.; CHABBI, A.; LEMAIRE, G.; CHARRIER, X.; RUMPEL, C. How does plant leaf senescence of grasslan species influence decomposition kinetics and litter compounds dynamics? Nutrient Cycling in Agroecosystems, v. 88, n. 2, p. 159-171, oct. 2010. https://doi.org/10.1007/s10705-009-9323-2

SILVA, D. J.; QUEIROZ, A. C. Análise de alimentos: métodos químicos e biológicos. 3.ed. Viçosa: UFV, 2006. $235 \mathrm{p}$.

SILVA NETO, L. F.; INDA, A. V.; BAYER, C.; DICK, D. P.; TONIN, A. T. Óxidos de ferro em Latossolos tropicais e subtropicais brasileiros em plantio direto. Revista Brasileira de Ciência do Solo, Viçosa, v. 32, n. 5, p. 1873-1881, jul. 2008.

SOUZA, A. P.; LIMA, M. E.; CARVALHO, D. F.; GUERRA, J. G. M.; ANDRADE, I. P. S.; ROCHA, H. S. Influência da decomposição de diferentes resíduos vegetais submetidos a lâminas de irrigação no comportamento da vegetação espontânea. Acta Scientiarum Agronomy, Maringá, v. 32, n. 2, p. 317-324, abr. 2010. https://doi.org/10.4025/actasciagron.v32i2.3732

THOMAS, R. J.; ASAKAWA, N. M. Decomposition of leaf litter from tropical forage grasses and legumes. Soil Biology and Biochemistry, Oxford, v. 25, n. 10, p. 1351-1361, oct. 1993. https://doi.org/10.1016/00380717(93)90050-L

TEDESCO, M. J.; GIANELLO, C.; BISSANI, C. A.; BOHNEN, H., VOLKWEISS, S. J. Análises de solo, plantas e outros materiais. Universidade Federal do Rio Grande do Sul, Porto Alegre, Boletim Técnico, Porto Alegre, n. 5, 2. ed. 1995, 174p.

TEIXEIRA, M. B; LOSS, A.; PEREIRA, M. G.; PIMENTEL, C. Decomposição e liberação de nutrientes da parte aérea de plantas de milheto e sorgo. Revista Brasileira de Ciência do Solo, Viçosa, v. 35, n. 3, p. 867876, jun. 2011.

TEIXEIRA, C. M.; LOSS, A.; PEREIRA, M. G.; PIMENTEL, C. Decomposição e ciclagem de nutrientes dos resíduos de quatro plantas de cobertura do solo. Idesia, Chile, v. 30, n. 1, p. 55-64, jan./abr. 2012. https://doi.org/10.4067/S0718-34292012000100007

TORRES, J. L. R.; PERREIRA, M. G. Dinâmica do potássio nos resíduos vegetais de plantas de cobertura no Cerrado. Revista Brasileira de Ciência do Solo, Viçosa, v. 32, n. 4, p. 1609-1618, jul./ago. 2008. 
VILELA, L.; MARTHA JUNIOR, G. B.; MACEDO, M. C. M.; MARCHÃO, R. L.; GUIMARÃES JÚNIOR, R.; PULROLNIK, K.; MACIEL, G. A. Sistemas de integração lavoura-pecuária na região do Cerrado. Pesquisa Agropecuária Brasileira, Brasília, v. 46, n. 10, p. 1127-1138, out. 2011. https://doi.org/10.1590/S0100-204X2011001000003 